\title{
Capital Structure over the Business Cycle*
}

\author{
David Amdur \\ Georgetown University ${ }^{\dagger}$
}

This Version: July 2009

\begin{abstract}
Why are aggregate equity payouts and debt issued positively correlated over the business cycle in U.S. data? Standard real business cycle (RBC) models have few predictions about capital structure, because they assume that financial markets are frictionless. On the other hand, the tradeoff theory of capital structure argues that financial frictions determine firms' optimal mix of debt and equity financing. I develop an RBC model with financial frictions and use it to explain some stylized facts about aggregate U.S. debt and equity flows. I document that debt issued and equity payouts are (i) positively correlated with output, (ii) positively correlated with investment, and (iii) positively correlated with each other. The model can account for these stylized facts. I also calibrate the model to the periods $1952-1983$ and $1984-2007$ in order to explain the finding that real variables have become less volatile in the later subperiod, while financial variables have become more volatile. By varying both the scale of technology shocks and the degree of financial frictions, the model can account for both results.
\end{abstract}

JEL Classification: E32, G32, G35

Keywords: Debt-equity finance, RBC models, business cycle moderation, corporate finance, capital structure, tradeoff theory, payout policy

${ }^{*}$ I would like to thank Martin D.D. Evans, Behzad Diba, Jinhui Bai and Olena Mykhaylova, as well as seminar participants at Georgetown University and the Midwest Economics Association annual meetings.

${ }^{\dagger}$ Department of Economics, 580 ICC, 37th and O Streets, NW, Washington, DC 20057. E-Mail: dpa3@georgetown.edu. 


\section{Introduction}

When output is high, U.S. firms as a whole issue more debt, invest more, and pay more to shareholders. Debt issued and equity payouts are both positively correlated with investment and positively correlated with each other. These findings suggest that firms use debt financing both to invest in their operations and to increase payments to shareholders. While borrowing to finance investment is well understood, borrowing to pay shareholders is more puzzling. Why would firms systematically transfer resources from bondholders to shareholders over the business cycle?

The workhorse model for analyzing business cycle correlations among macroeconomic variables is the real business cycle (RBC) model. However, traditional RBC models abstract from firm financing decisions. In the standard setup, a representative consumer-firm has access to a neoclassical production function and makes optimal consumption-investment decisions given a known stochastic process for productivity. ${ }^{1}$ An implicit assumption is that firms can costlessly reallocate resources in order to maximize the consumer's lifetime expected utility. A consequence of this approach is that conventional RBC models have little to say about financial behavior over the business cycle.

In reality, of course, firms have an array of options for financing their activities. In particular, firms can raise capital by borrowing at a fixed interest rate, by issuing equities, or by using internal funds. The classic paper by Modigliani and Miller (1958) showed that if capital markets are frictionless, firms should be indifferent regarding their capital structure. However, a common view in the corporate finance literature is that firms pursue a financial mix that balances the costs and benefits of different forms of finance (Leary and Roberts (2005)). According to this "tradeoff theory" of capital structure, financial frictions such as interest tax deductions and bankruptcy costs pin down a firm's optimal debt-equity ratio (see, for example, Scott (1976) and Miller (1977)). In a wide-ranging survey of CFOs conducted by Graham and Harvey (2001), most respondents reported that they have at least a loose target for their firms' debt-equity ratio. Many of the participants stated that interest tax deductions and credit ratings influence decisions about how much debt to issue.

In this paper I add a corporate finance decision to a standard RBC model. Firms decide how much debt to issue and how much to pay shareholders by weighing the costs and benefits of debt and equity financing. My goal is to explain some stylized facts about aggregate debt and equity flows in U.S. data. First, aggregate corporate borrowing and payouts to shareholders are almost always positive throughout the postwar period $(1952-2007)$. Second, debt issuance and net equity payouts are (i) positively correlated with output, (ii) positively correlated with investment, and (iii) positively correlated with each other. Third, real variables have become less volatile in recent years, while financial variables have become more volatile.

The key feature of the model is a set of parameterized financial frictions. On the debt side, interest payments are tax deductible. This makes debt financing preferred to equity financing for

\footnotetext{
${ }^{1}$ For an example of a "standard" RBC model, see Hansen (1997).
} 
low levels of debt. However, I also require bondholders to pay a monitoring cost that is increasing in the firm's debt-to-capital ratio. The tradeoff between the debt tax shield and the monitoring costs determines the firm's optimal level of debt. On the equity side, I assume that it is costly for firms to adjust their payouts to shareholders. This assumption is consistent with evidence that firms tend to smooth dividends over time. It also captures, in a stylized way, the legal and accounting costs associated with issuing and repurchasing equity shares.

I calibrate the model to U.S. data for the postwar period 1952 - 2007. In contrast with a standard RBC model, my model predicts positive borrowing at all points in the business cycle. The model correctly implies that debt issuance and equity payouts are procyclical, positively correlated with investment, and positively correlated with each other. Finally, I calibrate the model to two separate time periods, 1952 - 1983 and 1984 - 2007, in order to explain the stylized facts described by Jermann and Quadrini (2007): namely, that real variables have become less volatile in the second subperiod, while financial variables have become more volatile. By varying both the scale of the technology shocks and the degree of financial frictions, the model can match both facts.

I interpret these results as evidence that the types of frictions modeled - tax incentives, debt monitoring costs, and equity adjustment costs - can help explain the degree to which firms use debt financing to increase payments to shareholders. The results also provide support for a "dynamic tradeoff theory" of capital structure: firms target an optimal debt-equity ratio, but the target evolves over time as economic conditions change.

This paper contributes to a growing literature on capital structure over the business cycle. The debt friction can be viewed as a reduced form of the debt enforcement problem in Bernanke et al. (1999). Relative to their model, my model allows for equity issuance. Covas and den Haan (2006), Levy and Hennessy (2007) and Jermann and Quadrini (2007) all present models of debt and equity financing over the business cycle. Covas and den Haan have a partial equilibrium model of debt and equity finance where the interest rate process is exogenous. In contrast, the risk-free rate in my model is determined endogenously in general equilibrium. Levy and Hennessy (2007) consider a general equilibrium problem where managers can finance investment with debt or equity but are allowed to divert resources from both bondholders and shareholders. I differ by assuming that the firm's objective is aligned with that of shareholders. In my model, the equity friction reflects adjustment costs rather than an explicit agency problem.

My model is most closely related to Jermann and Quadrini (2007). They present a model of debt and equity finance and use it to explain the reduced volatility of macroeconomic variables and increased volatility of financial variables over the past two decades. My paper differs in three main ways. First, the key shock in Jermann and Quadrini's main analysis is an asset price shock, whereas I consider a standard technology shock. Second, Jermann and Quadrini's debt friction takes the form of an endogenous "debt ceiling", above which firms cannot borrow at any price. In practice, however, firms do not face a strict ceiling on debt; rather, the cost of debt may increase if firms borrow excessively. I attempt to capture this phenomenon through monitoring costs. Third, 
while Jermann and Quadrini also consider a convex cost for equity payouts, their cost function is increasing in the deviation of today's equity payout from its long-term target. In contrast, my cost function is an adjustment cost: it is increasing in the deviation of today's equity payout from yesterday's payout. I argue that this more naturally captures the legal and financial costs that I am trying to model.

The rest of the paper is structured as follows. Section 2 documents some stylized facts about debt and equity flows. Section 3 explains the financial frictions that I attempt to model. Section 4 presents the model. Section 5 discusses calibration and presents the results. Section 6 concludes.

\section{Debt and Equity Flows in the U.S.}

In this section I discuss the empirical features of debt and equity flows that I would like my model to capture. Figure 1 plots aggregate debt issued, equity payouts, and real fixed investment in the U.S. nonfarm sector, measured in billions of 2000 dollars. Data are quarterly flows from the Federal Reserve's Flow of Funds and the BEA's NIPA accounts (for fixed investment) for the period 1952:1 - 2007:4. I convert nominal flows to real flows using the BEA price index for value-added in the nonfarm sector. "Debt Issued" is the net increase in credit market liabilities over the quarter. A negative number reflects a net repayment of debt by businesses. "Equity Payout" equals dividends plus net repurchases of equity shares in the corporate sector, less proprietors' net investment in the noncorporate sector. The idea is to capture net flows to shareholders as a group, including small business owners. I view dividends and equity issues as two sides of the same coin: a firm that wishes to "raise capital" through equity may do so by lowering its dividend, by offering new shares, or both. Equivalently, a firm that wishes to "reward shareholders" may do so by increasing its dividend, by repurchasing shares, or both. The analysis reflect this presumed equivalence of dividends and share repurchases. ${ }^{2}$

A number of facts emerge from Figure 1. First, debt issued and net equity payouts are almost always positive over the postwar period. In aggregate, the U.S. business sector rarely issues equity or repurchases debt. Positive borrowing, in particular, suggests that some degree of leverage is optimal for firms. A second regularity is that debt issued and equity payouts are positively correlated. This close co-movement is especially striking beginning in the late 1980s. This suggests that net debt issuance and equity issuance are substitutes for firms. ${ }^{3}$ Third, both debt issued and equity payouts are positively correlated with investment. Finally, debt issued and equity payouts are considerably more volatile in the second half of the period.

Table 1 computes business cycle correlations for equity payouts, debt issued, real GDP and real fixed investment. I have detrended all variables with a Hodrick-Prescott filter. Debt issued and equity paid are both positively correlated with GDP ("procyclical"), positively correlated with

\footnotetext{
${ }^{2}$ Jermann and Quadrini (2007) also consider net equity payouts, measured in a similar way.

${ }^{3}$ Contrast this with Covas and den Haan (2006), who find that debt and gross equity issuance are complements. Covas and den Haan do not subtract share repurchases from equity issuance.
} 
investment, and positively correlated with each other. These findings suggest that firms borrow more heavily during booms. Firms apparently use the proceeds from borrowing both to invest and to finance higher payments to shareholders.

Table 2 presents business cycle volatilities for the two subperiods $1952-1983$ and $1984-2007$. Debt issued and equity payouts (as shares of GDP) have become more volatile. ${ }^{4}$ In contrast, real GDP and real investment have become less volatile, a well-documented phenomenon known as business cycle moderation.

I summarize the stylized facts from this section as follows. First, aggregate debt issued and equity payments to shareholders are almost always positive over the business cycle. Second, debt issued and equity payouts are (i) positively correlated with output, (ii) positively correlated with investment, and (iii) positively correlated with each other. Third, debt issued and equity payouts have become more volatile starting in 1984, while real variables have become less volatile.

The next section describes and motivates the financial frictions that I model. Section 4 presents the full model.

\section{Financial Frictions}

Conceptually, firms can finance their activities with debt, equity, or internal funds. In the model, debt financing takes place through one-period corporate bonds. Corporate bonds are issued by firms and pay a "quoted" interest rate $r_{t}$, but they require costly monitoring to ensure repayment. Consumers are the investors are in this model, so they pay the monitoring costs. Monitoring costs for a firm's debt are assumed to be a linear function of the firm's debt-to-capital ratio $L_{t}$, which consumers take as given. The price of a corporate bond to consumers is given by:

$$
P_{t}^{B, C}=\frac{1}{1+r_{t}}+\mu L_{t}
$$

$\mu$ is an exogenous parameter that controls the scale of the debt friction. Monitoring costs can be motivated as follows. Each period a firm could, in principle, default on its debt and enter a state of bankruptcy. Default is more likely the larger the amount borrowed relative to the firm's capital stock, which serves as collateral. Assume that bankruptcy is a distress state with unavoidable deadweight losses. In this setting, monitoring costs can be interpreted as a safety buffer against potential bankruptcy costs. Despite this motivation, I do not explicitly model bankruptcy. In particular, there is no default in equilibrium: investors always pay the monitoring costs, and the firm always repays its debt. ${ }^{5}$

\footnotetext{
${ }^{4}$ I scale equity payouts and debt issued by nominal GDP (value-added in the nonfarm sector) when computing volatilities. The increase in volatility is even more dramatic when these variables are not scaled by GDP. Measured in billions of chained 2000 dollars, the volatility of equity payouts increased by a factor of 3.78 and the volatility of debt issued increased by a factor of 2.48 .

${ }^{5} \mathrm{~A}$ deeper foundation for monitoring costs would require explicitly modeling the bankruptcy-inducing event. A
} 
An alternative interpretation of the debt friction is that it reflects a rating effect. There is ample evidence that firms are concerned about credit ratings when deciding how much debt to issue; see Graham and Harvey (2001) and Kisgen (2006). One of the metrics that rating agencies use to evaluate creditworthiness is a firm's debt-to-capital ratio. Figure 2 shows the median debtto-capital ratio for firms with different credit ratings. Firms with higher debt-to-capital ratios tend to have lower ratings. ${ }^{6}$ It is also well known that lower-rated corporate bonds have greater yields than higher-rated bonds. Therefore, it is more costly for firms with low credit ratings to issue corporate debt. The monitoring cost in (1) can thus be interpreted as reflecting the effect of higher debt levels on the cost of debt via a lower credit rating.

Interest paid on corporate debt in the U.S. is tax-deductible to the firm, a concept known as the "debt tax shield". The price that a firm receives for issuing a one-period corporate bond is therefore given by:

$$
P_{t}^{B, F}=\frac{1}{1+(1-\tau) r_{t}}
$$

$\tau$ is the marginal corporate tax rate. Note that the effective cost of debt to the firm is $(1-\tau) r_{t}$. Note that in general, $P_{t}^{B, C}$ need not equal $P_{t}^{B, F}$. For example, in the model, the tax deduction enjoyed by firms is paid for by a lump-sum tax on consumers. This creates a wedge between the proceeds a firm receives from issuing a bond and the price that consumers pay for a bond. Since the firm perceives that it can issue bonds at a favorable price, it will want to issue a positive amount of debt. However, the price of corporate debt to consumers rises with the amount issued because of the monitoring costs described above. As the price of debt increases, consumer demand for corporate bonds declines. The tradeoff between the tax advantage and monitoring costs will pin down the equilibrium level of debt and the "quoted" rate $r_{t}$ in equilibrium.

On the equity side, I assume that it is costly for firms to adjust their payouts to shareholders. Conceptually, the equity payout in the model reflects net flows to shareholders: dividends plus repurchases of shares, net of new issues. I impose the following quadratic cost function for a firm that wishes to pay $D_{t}$ at time $t$, given last period's payout, $D_{t-1}$, and the capital stock carried over from last period, $K_{t-1}$ :

standard approach uses an idiosyncratic shock and a debt contract. The debt contract specifies an interest rate and a cutoff value for the shock above which the firm always repays. Examples include Bernanke et al. (1999) and Covas and den Haan (2006). I take a simplified approach to the debt friction in order to avoid the heterogeneity arising from idiosyncratic shocks. Since my focus is on aggregate fluctuations over the business cycle, little explanatory power is lost by making this simplification.

${ }^{6}$ Here, "capital" refers to a firm's outstanding debt plus its outstanding equity, which together equal the firm's assets. In the model, a firm's only asset is its capital stock. Therefore, I treat the "debt-to-capital ratio" in the model as the ratio of a firm's outstanding debt to its capital stock. 


$$
c\left(D_{t}, D_{t-1}, K_{t-1}\right)=D_{t}+\phi K_{t-1}\left(\frac{D_{t}}{D_{t-1}}-1\right)^{2}, \phi>0
$$

Note that the adjustment cost is increasing in the percentage change of today's payout from yesterday's payout. The parameter $\phi$ controls the scale of the adjustment cost. The convex functional form given here is consistent with evidence that firms tend to smooth dividends over time, an observation first made by Lintner (1956). It also consistent with evidence regarding the legal and accounting costs associated with issuing and repurchasing equity shares. For example, Hansen and Torregrosa (1992) and Atlinkilic and Hansen (2000) show that underwriting fees exhibit increasing marginal cost in the size of the equity offering. I note that the adjustment cost here differs from Jermann and Quadrini (2007) in an important way. My cost function is the deviation of today's equity payout from yesterday's payout, rather than the deviation of today's equity payout from its long-term target. In a model with persistent productivity shocks, the firm's optimal long-term target may be very different from its optimal short-term payout. For example, in a model that fluctuates around a steady-state, the optimal current payout to shareholders is typically larger than the steady-state payout whenever productivity is above its steady-state level. It is not clear why it should be expensive to be away from the long-term target if the current payout is optimal for shareholders. The cost function in (3) is a true adjustment cost: it is increasing in the percentage deviation of today's payout from yesterday's payout. Arguably, this specification more naturally describes the legal and accounting costs that I am trying to model.

Finally, a firm can of course finance its investment through the use of internal funds. In the model, "internal funds" consist of a firm's current output plus its undepreciated capital stock. I do not model capital adjustment costs, so it is costless for a firm to use its internal funds to increase or decrease its capital stock.

The financial frictions serve two roles in the model. First, they determine the firm's optimal (positive) level of debt even in the absence of stochastic shocks. Second, they affect the way in which the firm reacts to shocks. In response to a positive, persistent productivity shock, the firm would like to both increase investment (to take advantage of higher expected productivity) and pay more to shareholders (to pass on the unexpected increase in lifetime profitability). If debt is available and the cost of changing the equity payout is low, the firm accomplishes this by borrowing heavily to boost its capital stock and increase payments to shareholders. On the other hand, if the cost of adjusting equity is high, the firm seeks to avoid large swings in its payout. As a result, the firm increases payouts only gradually, and its borrowing is both lower in magnitude and delayed in time. 


\section{The Model}

The model economy consists of a continuum of identical consumers and a continuum of identical, perfectly competitive firms. First I specify the consumer's problem and the firm's problem. I then define an equilibrium and briefly discuss the solution procedure.

\subsection{Consumer's problem}

A representative consumer can hold one-period risk-free bonds, $\tilde{B}_{t}$, one-period corporate bonds, $B_{t}$, and shares of firms, $S_{t}$. Risk-free bonds pay the net interest rate $\tilde{r}_{t}$ with certainty. Corporate bonds are issued by firms and pay the "quoted" interest rate $r_{t}$, but they require costly monitoring in order to ensure repayment. Monitoring costs are assumed to be a linear function of the firm's debt-to-capital ratio $L_{t}$, which the consumer takes as given.

Each share pays a dividend $D_{t}$ and trades in the stock market at the price $P_{t}$. Every period, the consumer receives income from her portfolio and decides how much to consume, $C_{t}$, and how much to reinvest in the three assets. Denote all variables chosen or realized in period $t$ with the subscript $t$. Endogenous variables that are predetermined in period $t$ carry the subscript $t-1$. The consumer is infinitely-lived and maximizes the expected present discounted value of her utility, $E_{t} \sum_{j=0}^{\infty} \beta^{j} u\left(C_{t+j}\right)$, with $0<\beta<1$. The consumer's problem can be written recursively as follows:

$$
\begin{gathered}
W\left(\tilde{B}_{t-1}, B_{t-1}, S_{t-1}\right)=\max _{\tilde{B}_{t}, B_{t}, S_{t}}\left\{u\left(C_{t}\right)+E_{t}\left[\beta W\left(\tilde{B}_{t}, B_{t}, S_{t}\right)\right]\right\} \\
\text { s.t. } C_{t}+\left(\frac{1}{1+\tilde{r}_{t}}\right) \tilde{B}_{t}+P_{t}^{B, C} B_{t}+P_{t} S_{t}=\tilde{B}_{t-1}+B_{t-1}+\left(P_{t}+D_{t}\right) S_{t-1}-T_{t}
\end{gathered}
$$

$\mu$ is an exogenous parameter that controls the scale of the debt friction. A high $\mu$ implies that monitoring costs are very sensitive to the firm's debt-to-capital ratio. The consumer must also pay a lump-sum tax $T_{t}$, whose role will be explained later. The consumer's first-order conditions are as follows:

$$
\begin{gathered}
\left(\tilde{B}_{t}\right): \frac{1}{1+\tilde{r}_{t}}=E_{t}\left[M_{t+1}\right] \\
\left(B_{t}\right): P_{t}^{B, C}=E_{t}\left[M_{t+1}\right] \\
\left(S_{t}\right): P_{t}=E_{t}\left[M_{t+1}\left(P_{t+1}+D_{t+1}\right)\right] \\
\text { where } M_{t+1} \equiv \frac{\beta u^{\prime}\left(C_{t+1}\right)}{u^{\prime}\left(C_{t}\right)}
\end{gathered}
$$

Equations $(1),(6),(7)$ relate the corporate interest rate $r_{t}$ to the firm's debt-to-capital ratio $L_{t}$ and the risk-free rate $\tilde{r}_{t}$ : 


$$
\frac{1}{1+r_{t}}=\frac{1}{1+\tilde{r}_{t}}-\mu L_{t}
$$

I assume a standard CRRA utility function:

$$
u(C)=\frac{C^{1-\eta}}{1-\eta}, \eta>0
$$

\subsection{Firm's problem}

A representative firm operates a neoclassical production function $F\left(K_{t-1}, Z_{t} N_{t}\right)$ and maximizes the expected present discounted value of its stream of net equity payments to shareholders. $K_{t-1}$ is the firm's capital stock carried over from last period, $N_{t}$ is labor input, $Z_{t}$ is labor-augmenting technological progress, and $D_{t}$ is the net equity payout. Labor input $N_{t}$ is normalized to 1 for all $t$; I abstract from fluctuations in labor supply. ${ }^{7}$ Since the firm is owned by consumers, it discounts payments to be made at time $j>t$ using the consumer's stochastic discount factor, $M_{t+j} \equiv \beta u^{\prime}\left(C_{t+j}\right) / u^{\prime}\left(C_{t}\right)$. The firm attains its new capital stock $K_{t}$ by issuing corporate bonds $B_{t}$ and by adjusting its net equity payout $D_{t}$. Interest paid on corporate bonds is tax-deductible, as given by (2). Finally, the firm faces a quadratic adjustment cost when changing its equity payout, as given by (3). The firm's problem can be written recursively as follows:

$$
\begin{gathered}
V\left(K_{t-1}, B_{t-1}, D_{t-1}\right)=\max _{B_{t}, D_{t}, K_{t}}\left\{D_{t}+E_{t}\left[M_{t+1} V\left(K_{t}, B_{t}, D_{t}\right)\right]\right\} \\
+\lambda_{t}\left\{F\left(K_{t-1}, Z_{t}\right)+(1-\delta) K_{t-1}+P_{t}^{B, F} B_{t}-B_{t-1}-c\left(D_{t}, D_{t-1}, K_{t-1}\right)-K_{t}\right\}
\end{gathered}
$$

$\lambda_{t}$ is the Lagrange multiplier on the firm's budget constraint, $\delta$ is the depreciation rate of capital, and $\tau$ is the marginal corporate tax rate. I impose the following functional form for the production function:

$$
F\left(K_{t-1}, Z_{t}\right)=K_{t-1}^{\alpha} Z_{t}^{1-\alpha}, \alpha \in(0,1)
$$

The firm's budget constraint, with functional forms imposed, is as follows:

$$
K_{t}=K_{t-1}^{\alpha} Z_{t}^{1-\alpha}+(1-\delta) K_{t-1}+\frac{B_{t}}{1+(1-\tau) r_{t}}-B_{t-1}-D_{t}-\phi K_{t-1}\left(\frac{D_{t}}{D_{t-1}}-1\right)^{2}
$$

\footnotetext{
${ }^{7}$ It would be straightforward to extend the model to incorporate a labor-leisure decision along the lines of Hansen (1997).
} 
In the Appendix I derive three Euler Equations for the firm - one each for bonds, dividends, and capital. The Euler Equations are:

$$
\begin{gathered}
\left(B_{t}\right): \frac{\lambda_{t}}{1+(1-\tau) r_{t}}=E_{t}\left[M_{t+1} \lambda_{t+1}\right] \\
\left(D_{t}\right): 1+E_{t}\left[2 \phi M_{t+1} \lambda_{t+1}\left(\frac{K_{t}}{D_{t}}\right)\left(\frac{D_{t+1}}{D_{t}}\right)\left(\frac{D_{t+1}}{D_{t}}-1\right)\right]= \\
\lambda_{t}\left[1+2 \phi\left(\frac{K_{t-1}}{D_{t-1}}\right)\left(\frac{D_{t}}{D_{t-1}}-1\right)\right] \\
\left(K_{t}\right): E_{t}\left[M_{t+1} \lambda_{t+1}\left\{\alpha\left(\frac{Z_{t+1}}{K_{t}}\right)^{1-\alpha}+(1-\delta)-\phi\left(\frac{D_{t+1}}{D_{t}}-1\right)^{2}\right\}\right]=\lambda_{t}
\end{gathered}
$$

Define the debt-to-capital ratio $L_{t}$, which appears in the household's problem, as follows:

$$
L(t) \equiv \frac{B_{t}}{K_{t-1}}
$$

The debt-to-capital ratio is defined as the ratio of the firm's outstanding debt to its capital stock, which is the firm's only asset. Note that consumers take the firm's debt-to-capital ratio as given when solving their portfolio allocation problem. This is justified theoretically by the assumption of infinitesimally "small" consumers: each consumer perceives that her decision about how much debt to hold does not affect the aggregate debt-to-capital ratio.

\subsection{Equilibrium and solution technique}

In equilibrium, the tax exemption on corporate bonds is financed by the lump-sum tax on households:

$$
T_{t}=\left\{\frac{\tau r_{t}}{\left[1+(1-\tau) r_{t}\right]\left(1+r_{t}\right)}\right\} B_{t}
$$

The risk-free bond $\tilde{B}_{t}$ is in zero net supply. On the other hand, corporate borrowing $B_{t}$ will always be strictly positive because of the tax advantage. I normalize shares $S_{t}$ to be 1 for all $t .^{8}$ In equilibrium, the consumer's budget constraint (5) then reduces to the following:

\footnotetext{
${ }^{8}$ Recall that conceptually, $D_{t}$ represents dividends plus net repurchases of shares. However, because I normalize $S_{t}$ to 1 for all $t, D_{t}$ equals dividends in the model, and there is technically no issuing or repurchasing activity. If firms were allowed to change both $D_{t}$ and the number of shares $S_{t}$, there would be an infinite set of optimal values for $\left(D_{t}, S_{t}\right)$. To avoid this indeterminacy, I fix the number of shares; but I could just as well have fixed the dividend level and let firms choose the number of shares. In the discussion that follows, I will continue to interpret $D_{t}$ as dividends plus net repurchases of shares.
} 


$$
C_{t}=D_{t}+B_{t-1}-\left[\frac{1}{1+(1-\tau) r_{t}}+\mu L_{t}\right] B_{t}
$$

I close the model by specifying a stochastic process for log productivity $z_{t}$.

$$
\begin{gathered}
z_{t}=z_{1 t}+z_{2 t} \\
\Delta z_{1 t}=\left(1-\rho_{1}\right) g+\rho_{1} \Delta z_{1 t-1}+\epsilon_{1 t},\left|\rho_{1}\right|<1 \\
z_{2 t}=\rho_{2} z_{2 t-1}+\epsilon_{2 t},\left|\rho_{2}\right|<1 \\
E\left[\epsilon_{1 t}\right]=E\left[\epsilon_{2 t}\right]=0, \operatorname{Var}\left[\epsilon_{1 t}\right]=\sigma_{1}^{2}, \operatorname{Var}\left[\epsilon_{2 t}\right]=\sigma_{2}^{2}
\end{gathered}
$$

This specification offers the flexibility of using a difference-stationary shock, an AR(1) shock, or a combination of both. An equilibrium is a sequence of prices and allocations such that all markets clear when consumers and firms behave optimally, taking equilibrium prices as given.

I characterize the equilibrium in two steps. First, I find the unique nonstochastic balanced growth path (BGP) equilibrium where the variables $Z_{t}, K_{t}, B_{t}, D_{t}, C_{t}$ and $P_{t}$ all grow at a constant rate and the variables $L_{t}, M_{t}, \tilde{r}_{t}, r_{t}$, and $\lambda_{t}$ are constant. Next, I log-linearize the equations of the model around the nonstochastic BGP. This generates a system of linear expectational difference equations in a set of stationary variables. Finally, I solve this system computationally using a technique described by Uhlig (1997). The result is an equilibrium law of motion and an equilibrium policy rule.

\section{Results}

In this section I present results from simulating the model described in the previous section. First, I explain how the model was calibrated. I then show and discuss impulse response functions for debt and equity flows. Next, I discuss simulation results for the overall period $1952-2007$. Finally, I calibrate the model to the two subperiods 1952 - 1983 and 1984 - 2007 in order to account for the change in volatilities of real and financial variables over the past two decades.

\subsection{Calibration}

Table 3 summarizes the calibrated parameter values for the model. I set $\eta$, the consumer's coefficient of relative risk aversion, to 2 , a commonly used value in empirical macro studies. In the benchmark specification, I use an $\operatorname{AR}(1)$ shock only, so there is no trend growth $(g=0)$. I set the persistence of the shock, $\rho_{2}$, to 0.95 . The share of capital in income, $\alpha$, is set to 0.40 , and the quarterly 
depreciation rate, $\delta$, is set to 0.02. Following Jermann and Quadrini (2007), I set the marginal corporate tax rate $\tau$ to 0.30 .

The rest of the parameters are calibrated to match particular moments in quarterly data for the U.S. nonfarm business sector over the period 1952:1 - 2007:4. Given the assumption of no trend growth, the subjective discount factor $\beta$ pins down the real risk-free rate. I take the real risk-free rate to be the average annualized yield on three-month Treasury bills over the quarter, net of inflation. ${ }^{9}$ This rate is $1.30 \%$, which corresponds to a quarterly value of 0.99675 for $\beta$. I scale the technology shocks to match the standard deviation of GDP over the time period.

Given $\tau$, the debt friction $\mu$ determines the steady-state level of corporate borrowing. A higher $\mu$ makes the cost of borrowing more sensitive to the amount borrowed, which in turn leads to less borrowing in the steady-state. I calibrate $\mu$ to match the average debt-to-GDP ratio in the nonfarm sector. The value of that ratio is 0.62 , which corresponds to a value for $\mu$ of 0.0384 . The equity friction parameter $\phi$ captures the cost of adjusting the firm's equity payout. A higher $\phi$ results in "smoother" equity payouts over time. I calibrate $\phi$ to match the standard deviation of net equity payouts as a share of GDP. The volatility in the data is 1.14, corresponding to a value for $\phi$ of $0.000655^{10}$

\subsection{Impulse Responses}

To fix intuition, it is helpful to look at impulse response functions for debt and equity flows. First, consider a frictionless RBC model with no debt financing and no equity adjustment cost. I represent this in the model by removing $B_{t}$ as a choice variable and setting $\phi=0$. Consumption in this model is just equal to the net equity payout. ${ }^{11}$ Figure 3 shows the impulse response function for net equity payouts in the frictionless model. All impulse responses are expressed in terms of percentage deviations from steady-state values. In response to a positive, persistent productivity shock, the firm immediately raises its payout. The intuition is that after the shock, the firm's expected lifetime profitability is suddenly higher. Since the firm's objective is to maximize shareholder utility, and since shareholders place positive weight on consumption today, the firm optimally raises its payout immediately. As time goes on, the firm accumulates capital, increases output and raises its equity payout still higher. Eventually, as the shock dies out, the firm's payout peaks and then declines back to its steady-state value. It is important to realize that although the equity payout goes up on impact, the firm is also investing more. Greater investment is optimal because high productivity today forecasts high productivity tomorrow, which increases tomorrow's expected marginal product of capital. Figure 4 shows the impulse response for investment. Since the firm is not raising equity

\footnotetext{
${ }^{9}$ I measure inflation as the annualized percent change in the CPI over the quarter.

${ }^{10} \mathrm{I}$ also tried the following variations, none of which significantly altered the results. (i) I tried values for $\eta$ in the range of 0.5 to 2 , including $\eta=1$ ( $\log$ utility). (ii) I used a difference stationary shock, first with $g=0$ and then with $g=\ln (1.5)$. (iii) I set $\alpha=0.3$. (iv) I set $\tau=0.2$, recalibrating $\mu$ as described above. Results available on request.

${ }^{11}$ See equation (21). Recall that when there are no frictions, debt is indeterminate; this is the classic prediction of Modigliani and Miller (1958). Therefore, in the frictionless model, I do not allow firms to borrow, and I set $B_{t}=0$ for all $t$.
} 
capital (it is instead increasing payments to shareholders), the firm finances its investment through its stock of internal funds. The firm prefers to finance using internal funds because issuing equity would detract too much from shareholder utility. Note that today's positive productivity shock increases the stock of internal funds available for both investment and equity payouts.

Now consider the full model with both debt and equity financing. Figure 5 shows impulses response for the equity payout. I consider two cases: the dashed line sets $\phi=0$, and the the solid line sets $\phi=0.000655$ (its calibrated value). Consider first the case of no equity adjustment cost (labeled "No Friction" in the figures). In response to a positive and persistent productivity shock, the equity payout now increases steeply on impact, then returns quickly to its steady-state value. The intuition is that with access to tax-advantaged debt, the firm can "borrow from bondholders to pay shareholders." Despite the apparent spike in the equity payout, consumers still face a relatively smooth consumption profile, as shown in Figure 7 . The reason is that consumers are also the bondholders in general equilibrium, and the net issuance of corporate bonds to consumers largely offsets the increase in equity payouts. Indeed, Figure 6 shows that with no equity adjustment cost, the firm's net issuance of debt on impact nearly equals the change in its equity payout. Unlike equity, however, debt declines gradually back towards its steady-state level. The ongoing issuance of debt finances capital investment; this is illustrated in Figure 8.

The introduction of the equity adjustment cost significantly dampens the firm's equity payout. In particular, Figure 5 shows that the increase of equity payouts on impact is less than one-fifth of the increase in the no-adjustment-cost scenario. Since adjustment costs are a pure deadweight loss, the firm faces a strong incentive to smooth its equity payout. As a result, the firm engages in much less "borrowing from bondholders to pay shareholders." Figure 6 shows that relative to the no-adjustment-cost case, the firm borrows less on impact and reaches peak borrowing only after a delay.

While the impact of the frictions on financial variables is significant, the impact on real allocations is very small. Figures 7 and 8 show that the impulse responses of consumption and investment do not change much when I add the calibrated equity adjustment cost. In addition, these impulse responses are very similar to their counterparts in the frictionless model with no debt. Contrast this result with Jermann and Quadrini (2007), where the severity of financial frictions has a significant effect on the impulse responses of real variables. The Jermann and Quadrini result depends on two key features not present in my model: (i) a debt ceiling above which the firm cannot borrow at any price, and (ii) an asset-price shock that alters the debt ceiling without affecting aggregate productivity. This suggests that the theoretical effect of financial frictions on the real economy depends critically on how both the frictions and the shocks are modeled.

\subsection{Volatilities and Cross Correlations}

Table 4 presents selected business cycle statistics from simulating the model and compares them with the corresponding moments in the data. I simulate the calibrated model by generating 50 
sample paths of 200 quarters each for productivity, discarding the first 100 quarters. I compute business cycle statistics for each sample path and take averages over the 50 samples. I apply an HP filter with a smoothing parameter of 1600 to both actual and simulated data. ${ }^{12}$ I consider the model with and without an equity adjustment cost. Looking at the standard deviations, the full model is able to replicate the volatility of the equity-payout-to-GDP ratio observed in the data. Recall that I calibrated $\phi$ to 0.000655 in order to match this moment. Although this may appear to be a small friction, it makes a big difference. When I set $\phi=0$, the implied volatility of equity payouts jumps from 1.14 to 6.51 - almost six times higher than in the data. As suggested by the impulse response functions, the adjustment cost results in "smoother" equity payouts over time.

Looking at correlations, equity payouts and debt issued are (i) positively correlated with output, (ii) positively correlated with investment, and (iii) positively correlated with each other, consistent with the stylized facts described in Section 2. These results hold both with and without equity adjustment costs. The tax advantage on debt, combined with monitoring costs, is sufficient to replicate these correlations. I interpret this as evidence that the interest tax deduction and concerns about excessive leverage influence the aggregate behavior of debt and equity flows over the business cycle.

These results also provide some evidence for a "dynamic tradeoff theory" of capital structure. Given the costs and benefits of debt, firms appear to target an optimal debt-equity ratio. However, the target itself changes over time as shocks impact firms' resources and alter their forecasts for future productivity. Of course, the evidence presented is all at the aggregate level. More convincing evidence of a dynamic tradeoff theory would require an empirical firm-level analysis, which is beyond the scope of this paper.

The model is somewhat less successful at matching the absolute values of some key volatilities. Note that the volatility of $(\mathrm{log})$ real GDP was calibrated to match the data. The model's volatility of investment is close to the data, as in standard RBC models. However, the model's volatility of debt is too high; and the model's volatilities for the ratio of outstanding debt to equity ("debtequity ratio") and the ratio of equity payments to equity outstanding ("payout-to-market-value") are too low. The latter two ratios depend in large part on the movement of stock prices in the data, which are much more volatile than predicted by most macro models. However, as I show below, the model is more successful at replicating changes in these volatilities over time.

\subsection{Changes in Volatilities over Time}

As documented in Section 2, the business cycle volatilities of output and investment have declined substantially starting in the mid-1980s, a well known phenomenon known as business cycle moderation. Jermann and Quadrini (2007) document that during the same period, the financial structure

\footnotetext{
${ }^{12}$ Results are similar when the simulated data is left unfiltered. Furthermore, the business cycle statistics in the data don't change much under alternative filters, such as the Baxter-King band-pass filter. Results available on request.
} 
of firms has become more volatile - a finding that I also replicated in Section 2. In particular, the volatility of equity payouts has increased by over $50 \%$ from the period $1952-1983$ to the period 1984 - 2005. In this section I demonstrate that the model can successfully account for the joint findings of dampened real volatility and increased financial volatility.

Since financial frictions do not have large real effects in my framework, I adopt the position of Arias et al. (2006) and assume that the decline in real volatility is a result of less volatile productivity shocks. For example, the second subperiod was not characterized by the oil supply disruptions and large swings in inflation that marked the 1970s. On the other hand, I assume that the increase in financial volatility was driven by innovations in financial markets that eased the frictions in the model. Such innovations include the wide adoption of securitized assets and SEC rules facilitating greater flexibility in equity offerings and repurchases; see Jermann and Quadrini (2007) for other examples.

I proceed by calibrating the volatility of technology shocks $\sigma_{2}$, the debt friction $\mu$ and the equity friction $\phi$ separately for each subperiod. As before, my calibration targets are the standard deviation of GDP, the average debt-GDP ratio and the standard deviation of the equity-payoutto-GDP ratio. Table 5 presents my results. The model is fairly successful at matching relative volatilities across the two time periods. Given that GDP volatility declined by about $50 \%$, the model predicts a $50 \%$ decline in the volatilities of real investment and consumption, consistent with the data. By calibrating $\mu, \mathrm{I}$ am able to match a $50 \%$ increase in the average value of the debt-to-GDP ratio. By calibrating $\phi$, I also reproduce the roughly $70 \%$ increase in the volatility of equity payouts. The model also matches, at least qualitatively, relative volatilities for four variables that were not calibration targets: the debt-issued-to-GDP ratio, the debt-equity ratio, the payout-to-market-value ratio, and the real risk-free rate. The results in Table 5 are calculated from HP-filtered data. Results from unfiltered data were similar and are available on request.

The model provides an alternative explanation for the joint findings of dampened real volatility and increased financial volatility over the past two decades. In my framework, the moderation in real business cycles is driven by the "good fortune" of less volatile productivity shocks, while the increase in financial volatility is a result of reduced financial frictions. Note that the reduction in financial frictions is sufficient to increase financial volatility even in the presence of dampened technology shocks, which by themselves would decrease financial volatility. In contrast, Jermann and Quadrini (2007) present a model where financial innovations drive both results. Their model relies on an asset price shock and an endogenous debt ceiling that transmits pure financial shocks to the real sector. In order to discriminate between the two explanations, one would need to pin down the relative importance of asset price shocks and technology shocks in the data. Identifying and quantifying different types of shocks involves many challenges, not the least of which is to arrive at meaningful and agreed-upon definitions. I defer this topic for future research. 


\section{Conclusion}

I have shown that an RBC model with an explicit capital structure decision can explain a number of stylized facts about aggregate debt and equity flows in U.S. data. I developed an augmented RBC model characterized by three financial frictions: a debt tax shield, debt monitoring costs, and (optionally) an equity adjustment cost. The tax shield and costly monitoring pin down an optimal, positive amount of debt issued. The equity adjustment cost allows for more realistic fluctuations of equity payouts in response to technology shocks. In calibrated simulations, the model correctly implies that debt issued and equity payouts are both positively correlated with GDP, positively correlated with investment, and positively correlated with each other. Finally, I use the model to explain the finding of Jermann and Quadrini (2007) that real variables have become less volatile over the last two decades, while financial flows have become more volatile. By varying both the scale of the technology shocks and the degree of financial frictions, I can account for both results.

A number of avenues are available for further research. One straightforward extension would be to estimate the key parameters of the model $(\mu$ and $\phi)$ using a simulated method-of-moments technique. This would potentially generate a better fit with the data. The model has implications for the capital structure decisions of individual firms. For example, firms with high tax exposure and firms that are easily monitored should make greater use of debt financing than other firms. Furthermore, as a firm's tax exposure and other characteristics change over time, its reliance on debt financing should also change. These implications could be tested in firm-level panel data. A more ambitious extension would involve extending the model to an international setting. A twocountry version of the model with trade in financial assets and asymmetric financial frictions would have predictions for debt and equity flows across countries. I plan to pursue these ideas in future work. 


\section{References}

Andres Arias, Gary D. Hansen, and Lee E. Ohanian. Why have business cycle fluctuations becomes less volatile? NBER Working Paper No. 12079, 2006.

Oya Atlinkilic and Robert S. Hansen. Are there economies of scale in underwriting fees? evidence of rising external financial costs. Review of Financial Studies, 13:191-218, 2000.

Ben S. Bernanke, Mark Gertler, and Simon Gilchrist. The financial accelerator in a quantitative business cycle framework. In John B. Taylor and Michael Woodford, editors, Handbook of Macroeconomics, volume 1C, chapter 21. Amsterdam: Elsevier Science, 1999.

Francisco Covas and Wouter J. den Haan. The role of debt and equity financing over the business cycle. Bank of Canada Working Paper 2006-45, 2006.

John R. Graham and Campbell R. Harvey. The theory and practice of corporate finance: Evidence from the field. Journal of Financial Economics, 60:187-243, 2001.

Gary D. Hansen. Technical progress and aggregate fluctuations. Journal of Economic Dynamics and Control, 21:1005-1023, 1997.

Robert S. Hansen and Paul Torregrosa. Underwriter compensation and corporate monitoring. Journal of Finance, 47:1536-1555, 1992.

Urban Jermann and Vincenzo Quadrini. Financial innovations and macroeconomic volatility. NBER Working Paper No. 12308, 2007.

Darren J. Kisgen. Credit ratings and capital structure. Journal of Finance, 61:1035-1072, 2006.

Mark T. Leary and Michael R. Roberts. Do firms rebalance their capital structures? Journal of Finance, pages 2575-2620, 2005.

Amnon Levy and Christopher Hennessy. Why does capital structure vary with macroeconomics conditions? Journal of Monetary Economics, 54:1545-1564, 2007.

John Lintner. Distribution of incomes of corporations among dividends, retained earnings, and taxes. American Economic Review, 46:97-113, 1956.

Merton Miller. Debt and taxes. Journal of Finance, 32:261-275, 1977.

Franco Modigliani and Merton Miller. The cost of capital, corporation finance and the theory of investment. American Economic Review, 48:261-297, 1958.

James H. Scott. A theory of optimal capital structure. Bell Journal of Economics, 7:33-54, 1976.

Harald Uhlig. A toolkit for analyzing nonlinear dynamic stochastic models easily. Center for Economics Research discussion paper, University of Tilburg, 1997. 


\section{Appendix}

\section{A Derivation of Euler Equations for Firm's Problem}

The firm's problem can be written as follows:

$$
\begin{gathered}
V\left(K_{t-1}, B_{t-1}, D_{t-1}\right)=\max _{B_{t}, D_{t}, K_{t}}\left\{D_{t}+E_{t} M_{t+1} V\left(K_{t}, B_{t}, D_{t}\right)\right\} \\
+\lambda_{t}\left\{F\left(K_{t-1}, Z_{t}\right)+(1-\delta) K_{t-1}+\frac{B_{t}}{1+(1-\tau) r_{t}}-B_{t-1}-c\left(D_{t}, D_{t-1}, K_{t-1}\right)-K_{t}\right\}
\end{gathered}
$$

Taking first-order conditions:

$$
\begin{gathered}
\left(B_{t}\right): E_{t} M_{t+1} V_{B}\left(K_{t}, B_{t}, D_{t}\right)+\frac{\lambda_{t}}{1+(1-\tau) r_{t}}=0 \\
\left(D_{t}\right): 1+E_{t} M_{t+1} V_{D}\left(K_{t}, B_{t}, D_{t}\right)-\lambda_{t} c_{1}\left(D_{t}, D_{t-1}, K_{t-1}\right)=0 \\
\left(K_{t}\right): E_{t} M_{t+1} V_{K}\left(K_{t}, B_{t}, D_{t}\right)-\lambda_{t}=0
\end{gathered}
$$

From the envelope conditions, we have:

$$
\begin{gathered}
V_{K}\left(K_{t}, B_{t}, D_{t}\right)=\lambda_{t+1}\left[F_{K}\left(K_{t}, Z_{t+1}\right)+(1-\delta)-c_{3}\left(D_{t+1}, D_{t}, K_{t}\right)\right] \\
V_{B}\left(K_{t}, B_{t}, D_{t}\right)=-\lambda_{t+1} \\
V_{D}\left(K_{t}, B_{t}, D_{t}\right)=-\lambda_{t+1} c_{2}\left(D_{t+1}, D_{t}, K_{t}\right)
\end{gathered}
$$

Substituting the envelope conditions back into the first-order conditions:

$$
\begin{gathered}
\left(B_{t}\right): \frac{\lambda_{t}}{1+(1-\tau) r_{t}}-E_{t} M_{t+1} \lambda_{t+1}=0 \\
\left(D_{t}\right): 1-E_{t} M_{t+1} \lambda_{t+1} c_{2}\left(D_{t+1}, D_{t}, K_{t}\right)-\lambda_{t} c_{1}\left(D_{t}, D_{t-1}, K_{t-1}\right)=0 \\
\left(K_{t}\right): E_{t} M_{t+1} \lambda_{t+1}\left[F_{K}\left(K_{t}, Z_{t+1}\right)+(1-\delta)-c_{3}\left(D_{t+1}, D_{t}, K_{t}\right)\right]-\lambda_{t}=0
\end{gathered}
$$

I impose the following functional forms for the production function and dividend-adjustment cost function:

$$
\begin{gathered}
F\left(K_{t-1}, Z_{t}\right)=K_{t-1}^{\alpha} Z_{t}^{1-\alpha}, \alpha \in(0,1) \\
c\left(D_{t}, D_{t-1}, K_{t-1}\right)=D_{t}+\phi K_{t-1}\left(\frac{D_{t}}{D_{t-1}}-1\right)^{2}, \phi>0
\end{gathered}
$$

Applying the functional forms above to equations (35), (36) and (37) gives the Euler Equations listed in the main text. 


\section{B Full List of Equations Characterizing Equilibrium}

For convenience, all the equations of the model are reproduced here:

$$
\begin{aligned}
& \frac{1}{1+\tilde{r}_{t}}=E_{t}\left[M_{t+1}\right] \\
& P_{t}=E_{t}\left[M_{t+1}\left(P_{t+1}+D_{t+1}\right)\right] \\
& M_{t} \equiv \frac{\beta u^{\prime}\left(C_{t}\right)}{u^{\prime}\left(C_{t-1}\right)} \\
& \frac{1}{1+r_{t}}=\frac{1}{1+\tilde{r}_{t}}-\mu L_{t} \\
& K_{t}=K_{t-1}^{\alpha} Z_{t}^{1-\alpha}+(1-\delta) K_{t-1}+\frac{B_{t}}{1+(1-\tau) r_{t}}-B_{t-1}-D_{t}-\phi K_{t-1}\left(\frac{D_{t}}{D_{t-1}}-1\right)^{2} \\
& \frac{\lambda_{t}}{1+(1-\tau) r_{t}}=E_{t} M_{t+1} \lambda_{t+1} \\
& 1+E_{t}\left\{2 \phi M_{t+1} \lambda_{t+1}\left(\frac{K_{t}}{D_{t}}\right)\left(\frac{D_{t+1}}{D_{t}}\right)\left(\frac{D_{t+1}}{D_{t}}-1\right)\right\}=\lambda_{t}\left\{1+2 \phi\left(\frac{K_{t-1}}{D_{t-1}}\right)\left(\frac{D_{t}}{D_{t-1}}-1\right)\right\} \\
& E_{t} M_{t+1} \lambda_{t+1}\left\{\alpha\left(\frac{Z_{t+1}}{K_{t}}\right)^{1-\alpha}+(1-\delta)-\phi\left(\frac{D_{t+1}}{D_{t}}-1\right)^{2}\right\}=\lambda_{t} \\
& L(t) \equiv \frac{B_{t}}{K_{t-1}} \\
& C_{t}=D_{t}+B_{t-1}-\left[\frac{1}{1+(1-\tau) r_{t}}+\mu L_{t}\right] B_{t} \\
& z_{t}=z_{1 t}+z_{2 t} \\
& \Delta z_{1 t}=\left(1-\rho_{1}\right) g+\rho_{1} \Delta z_{1 t-1}+\epsilon_{1 t},\left|\rho_{1}\right|<1 \\
& z_{2 t}=\rho_{2} z_{2 t-1}+\epsilon_{2 t},\left|\rho_{2}\right|<1 \\
& E\left[\epsilon_{1 t}\right]=E\left[\epsilon_{2 t}\right]=0, \operatorname{Var}\left[\epsilon_{1 t}\right]=\sigma_{1}^{2}, \operatorname{Var}\left[\epsilon_{2 t}\right]=\sigma_{2}^{2}
\end{aligned}
$$




\begin{tabular}{|c|c|}
\hline Variables & Correlation \\
\hline (Equity Payout, GDP) & 0.16 \\
(Debt Issued, GDP) & 0.45 \\
(Real Fixed Investment, GDP) & 0.90 \\
(Equity Payout, Real Fixed Investment) & 0.19 \\
(Debt Issued, Real Fixed Investment) & 0.52 \\
(Equity Payout, Debt Issued) & 0.38 \\
\hline
\end{tabular}

Table 1: Business cycle correlations for selected real and financial variables from 1952 - 2007. "Debt Issued" is the net increase in credit market liabilities. A negative number reflects a net repayment of debt by businesses. "Equity Payout" equals dividends plus net repurchases of equity shares in the corporate sector, less proprietors' net investment in the noncorporate sector. GDP is real gross value-added in the nonfarm business sector. All variables are detrended using a Hodrick-Prescott filter with a smoothing parameter of 1600. Sources: Flow of Funds, Federal Reserve Board and NIPA Accounts, BEA. 


\begin{tabular}{|c|c|c|c|}
\hline Standard Deviations $(\times 100)$ & 1952-1983 & 1984-2007 & Late/Early \\
\hline Equity Payout / GDP & 0.85 & 1.44 & 1.69 \\
Debt Issued / GDP & 1.32 & 1.69 & 1.28 \\
Log Real GDP & 2.56 & 1.18 & 0.46 \\
Log Real Fixed Investment & 5.58 & 3.63 & 0.65 \\
\hline
\end{tabular}

Table 2: Changes in selected business cycle statistics for the Nonfarm sector between 1952 - 1983 and 1984 - 2007. All variables are detrended using a Hodrick-Prescott filter with a smoothing parameter of 1600. Sources: Flow of Funds, Federal Reserve Board and NIPA Accounts, BEA. 


\begin{tabular}{|c|c|c|c|}
\hline Parameter & Value & Calibration Target & Target Value \\
\hline$\eta$ & 2 & Standard in literature & \multirow{2}{*}{$1.30 \%$} \\
$\beta$ & 0.99675 & Real risk-free rate & \\
$\mathrm{G}$ & 1 & Zero growth in steady-state & \\
$\alpha$ & 0.40 & Standard in literature & \\
$\delta$ & 0.02 & Standard in literature & \\
$\tau$ & 0.30 & Jermann and Quadrini & 2.09 \\
$\rho_{2}$ & 0.95 & Standard in literature & 0.62 \\
$\sigma_{2}$ & 0.0282 & Std dev of GDP (x100) & 1.14 \\
$\mu$ & 0.0384 & Mean of Debt / GDP \\
$\phi$ & 0.000655 & Std dev of Equity Payout / GDP (x100) & \\
\hline
\end{tabular}

Table 3: Calibration. 


\begin{tabular}{|c|c|c|c|}
\hline Standard Deviations $(\times 100)$ & Data & Full Model & $\phi=0$ \\
\hline Equity Payout / GDP & 1.14 & 1.14 & 6.49 \\
Debt Issued / GDP & 1.49 & 4.53 & 7.55 \\
Debt Outstanding / Equity Outstanding & 3.17 & 0.02 & 0.04 \\
Equity Payout / Equity Outstanding & 0.84 & 0.01 & 0.03 \\
Log Real GDP & 2.09 & 2.09 & 2.09 \\
Log Fixed Investment & 4.84 & 5.11 & 5.05 \\
\hline \multicolumn{3}{|c|}{} \\
\hline Correlations & Data & Full Model & $\phi=0$ \\
\hline (Equity Payout, GDP) & 0.16 & 0.81 & 0.39 \\
(Debt Issued, GDP) & 0.45 & 0.60 & 0.96 \\
(Real Fixed Investment, GDP) & 0.90 & 1.00 & 1.00 \\
(Equity Payout, Real Fixed Investment) & 0.19 & 0.83 & 0.40 \\
(Debt Issued, Real Fixed Investment) & 0.52 & 0.57 & 0.97 \\
(Equity Payout, Debt Issued) & 0.38 & 0.26 & 0.43 \\
\hline
\end{tabular}

Table 4: Standard deviations and correlations from data and model, HP-filtered. 


\begin{tabular}{|c|cc|cc|cc|}
\hline & \multicolumn{2}{|c|}{$1952-1983$} & \multicolumn{2}{c|}{$1984-2007$} & \multicolumn{2}{c|}{ Late/Early } \\
\hline Mean & Data & Model & Data & Model & Data & Model \\
\hline Debt Stock / GDP & 0.51 & 0.51 & 0.78 & 0.78 & 1.53 & 1.53 \\
\hline \hline Standard Deviations (× 100) & Data & Model & Data & Model & Data & Model \\
\hline Equity Payout / GDP & 0.85 & 0.86 & 1.44 & 1.44 & 1.69 & 1.67 \\
Debt Issued / GDP & 1.32 & 3.70 & 1.69 & 3.76 & 1.28 & 1.02 \\
Debt Outst. / Equity Outst. & 2.83 & 0.02 & 3.57 & 0.02 & 1.26 & 1.11 \\
Equity Payout / Equity Outst. & 0.72 & 0.00 & 0.98 & 0.01 & 1.36 & 1.76 \\
Log Real GDP & 2.56 & 2.56 & 1.18 & 1.18 & 0.46 & 0.46 \\
Log Investment & 5.58 & 6.30 & 3.63 & 2.86 & 0.65 & 0.45 \\
Log Consumption & 1.47 & 0.63 & 0.73 & 0.29 & 0.49 & 0.46 \\
Real T-Bill Rate & 133.04 & 0.08 & 124.73 & 0.03 & 0.94 & 0.40 \\
\hline
\end{tabular}

Table 5: Changes in business cycle statistics for the Nonfarm sector between $1952-1983$ and 1984 $-2007$. 


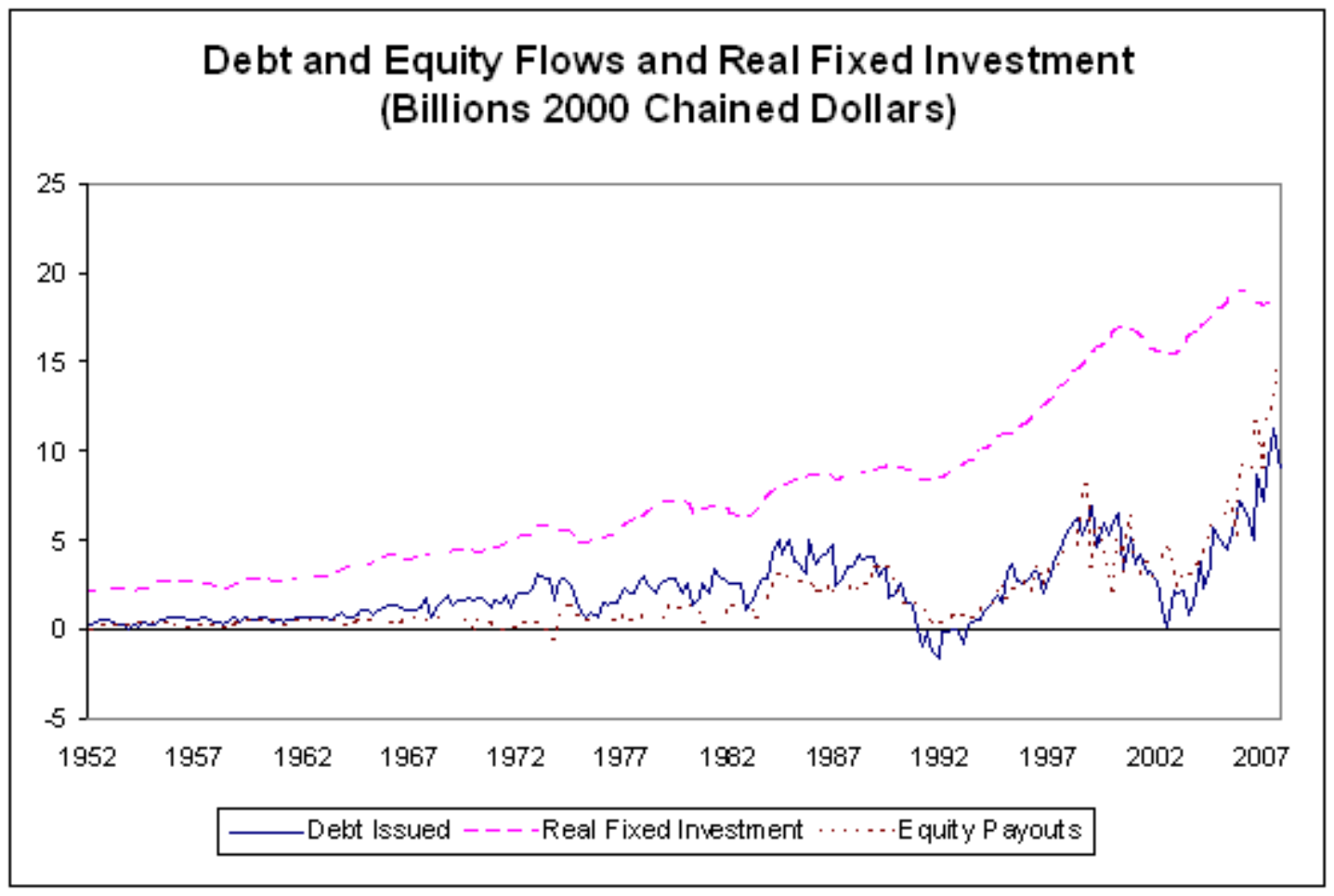

Figure 1: Aggregate debt and equity flows and aggregate real investment in the U.S. nonfarm sector, in billions of chained 2000 dollars. Sources: Flow of Funds, Federal Reserve Board and NIPA Accounts, BEA. 


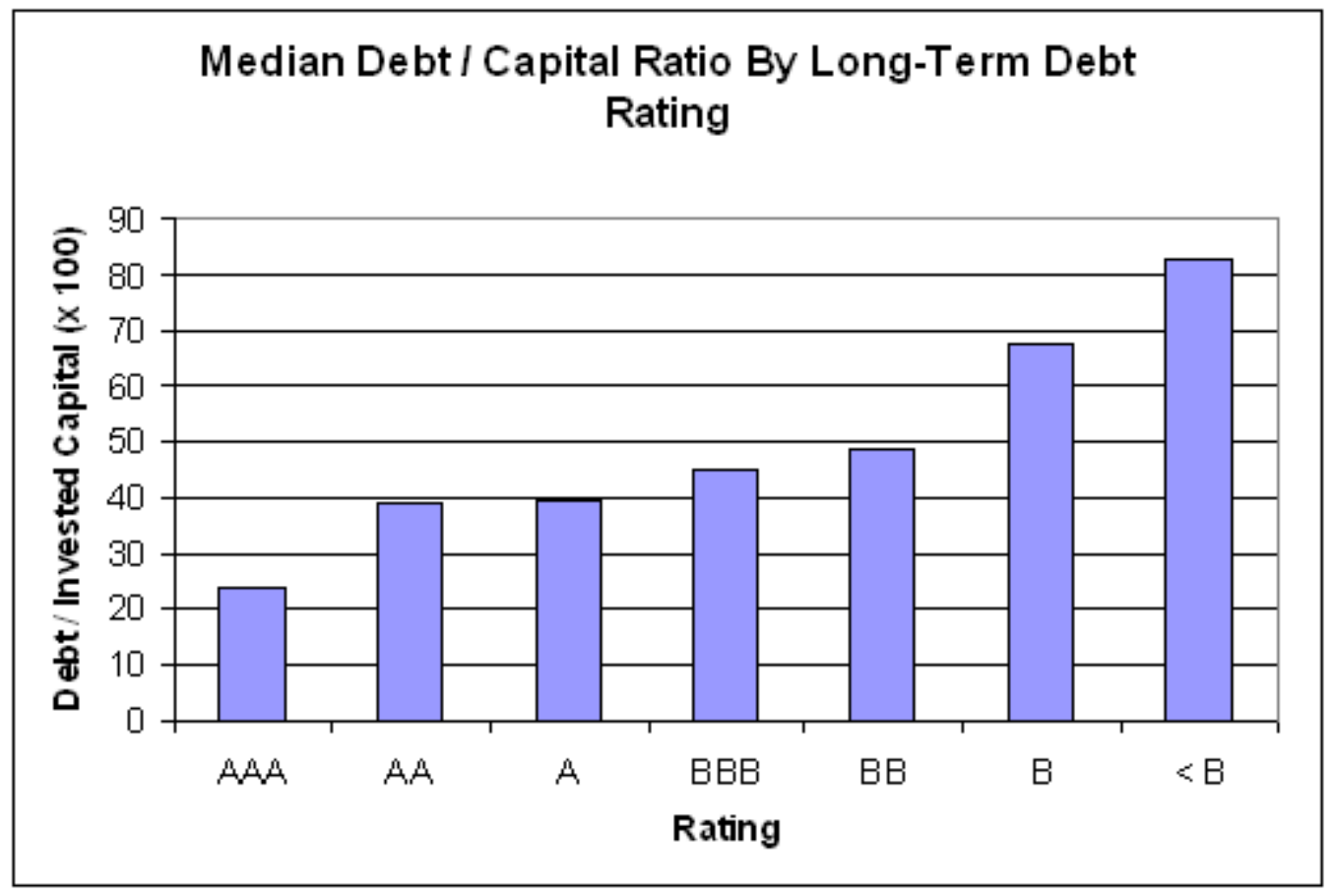

Figure 2: Median debt-to-capital ratios for firms by long-term S\&P credit rating. Here "capital" refers to a firm's outstanding debt plus its outstanding equity, which together equal the firm's assets. Each bar in the graph plots the median debt-to-capital ratio among all active Compustat firms with the given credit rating. Source: Compustat, author's calculations. 


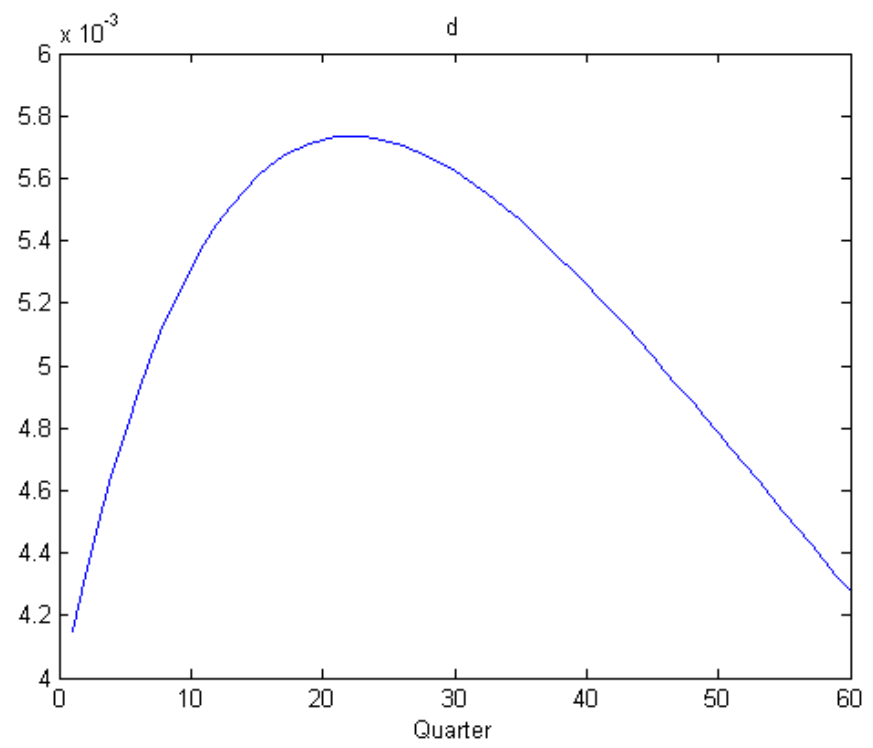

Figure 3: Impulse response for net equity payout in a frictionless model.

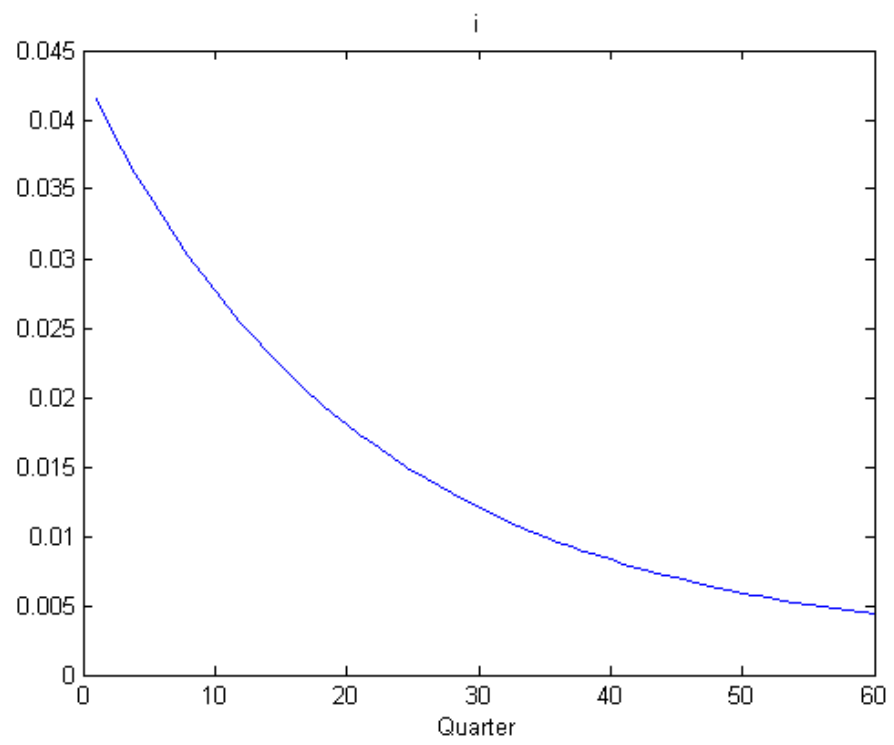

Figure 4: Impulse response for investment in a frictionless model. 


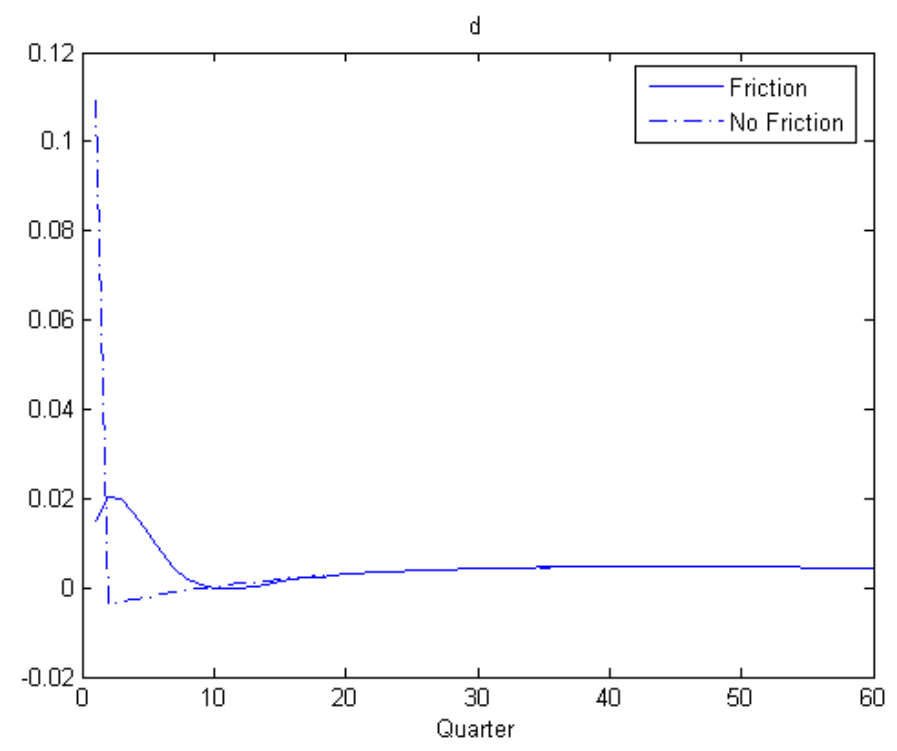

Figure 5: Impulse responses for net equity payout.

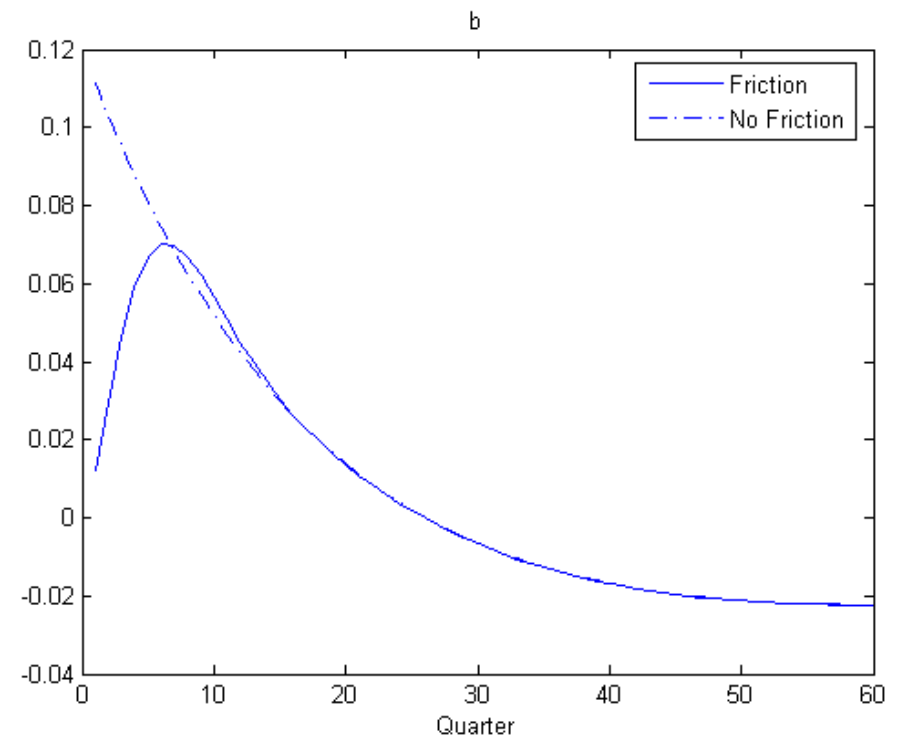

Figure 6: Impulse responses for debt. 


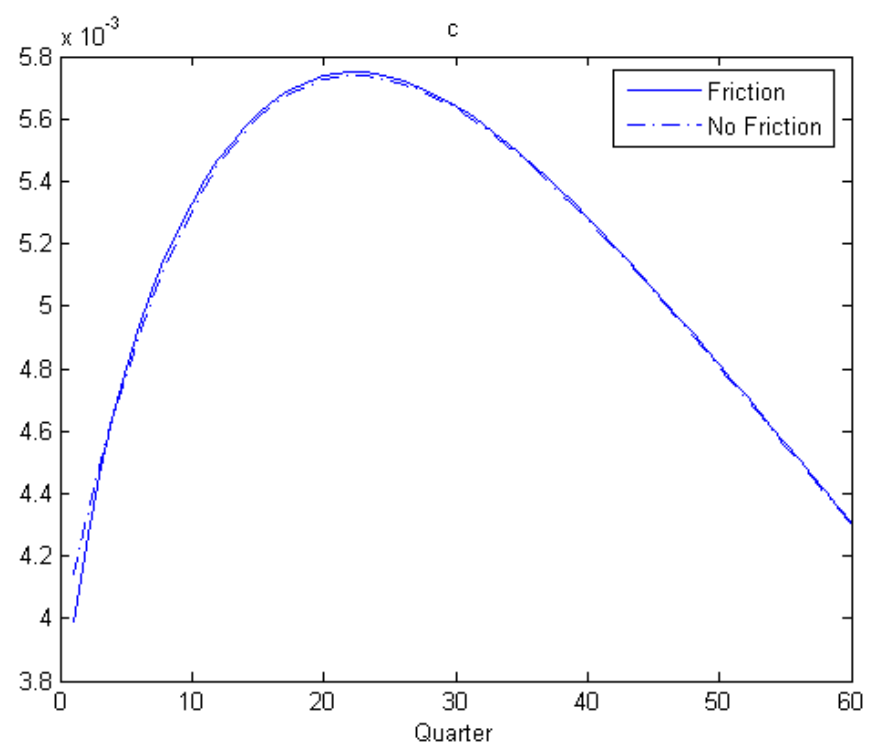

Figure 7: Impulse responses for consumption.

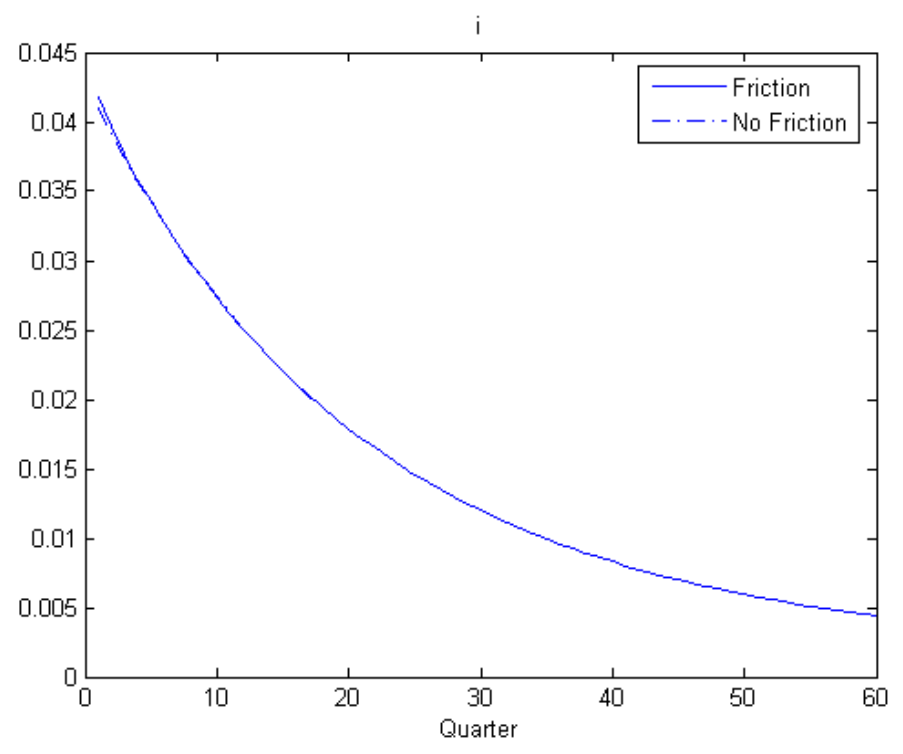

Figure 8: Impulse responses for investment. 